\title{
História pública, comemorações e ensino de história: o centenário da República no Brasil (1989-1992)
}

Public History, Commemorations and History Teaching: The Centenary of the Republic in Brazil (1989-1992)

Ricardo Oriá *, 1

\section{Resumo}

$\mathrm{O}$ artigo tem como objetivo analisar a relação entre História Pública e a construção da memória nacional, ressaltando-se o papel do Parlamento Brasileiro nesse processo, sobretudo durante a elaboração de um novo ordenamento jurídico. As Constituições republicanas trouxeram dispositivos de memória, cujo objetivo era homenagear determinados sujeitos históricos, seja pela construção de monumentos, seja pela instituição de datas cívicas e comemorações. Pretendemos mostrar que tal postura reforçou, no ensino de história, uma prática de exaltação dos heróis nacionais e um currículo escolar pautado pela comemoração de efemérides. No âmbito das comemorações do Centenário da República, Tiradentes e Deodoro serão os primeiros a serem alçados à condição de heróis nacionais no Panteão da Pátria, no dia 15 de novembro de 1989, em pleno feriado nacional.

Palavras-chave: história pública; comemorações; ensino de história; heróis nacionais.

\section{Abstract}

The article aims to analyze the relationship between Public History and the construction of national memory, highlighting the role of the Brazilian Parliament in this process, especially during the drafting of a new legal system. The republican constitutions brought memory devices, whose purpose was to honor certain historical subjects, either through the construction of monuments, or by the institution of civic dates and celebrations. We intend to show that this position reinforced, in the teaching of history, a practice of exaltation of the national heroes and a school curriculum based on the commemoration of ephemeris. In the framework of the commemorations of the Centennial of the Republic, Tiradentes and Deodoro will be the first to be elevated to the status of national heroes in the National Pantheon, on November 15, 1989, during the national holiday.

Keywords: Public History; commemorations; History teaching; national heroes.

* Câmara dos Deputados, Consultor Legislativo da área de Educação e Cultura, Brasília, DF, Brasil.groof@uol.com.br 
Seja um pálio de luz desdobrado,

Sob a larga amplidão destes céus.

Este canto rebel, que o passado

Vem remir dos mais torpes labéus!

Seja um hino de glória que fale

De esperanças de um novo porvir!

Com visões de triunfos embale

Quem por ele lutando surgir!

[Refrão]

Liberdade! Liberdade!

Abre as asas sobre nós,

Das lutas na tempestade

Dá que ouçamos tua voz.

(Hino da Proclamação da República) ${ }^{2}$

O Hino da Proclamação da República ${ }^{3}$ não é tão conhecido quanto o Hino Nacional. Sua letra rebuscada e a não obrigatoriedade de seu estudo na escola fundamental ${ }^{4}$ são fatores que contribuíram para isso. Mas, em fevereiro de 1989, seu refrão caiu no gosto popular, quando no carnaval do Rio de Janeiro, a Escola de Samba Imperatriz Leopoldinense, ao homenagear o centenário da República, que se comemorava naquele ano, usou um trecho desse hino no seu samba-enredo: "Liberdade, Liberdade, abre as asas sobre nós/ Que a voz da igualdade seja sempre a nossa voz". A escola sagrou-se campeã do desfile.

Um ano antes, em 5 de outubro de 1988, era promulgada uma nova Constituição. Sugestivamente chamada pelo então presidente da Assembleia Constituinte, deputado federal Ulysses Guimarães, de "Constituição Cidadã", por ampliar consideravelmente os direitos e garantias fundamentais do cidadão, ela trazia também, em seu bojo, dois dispositivos que eram inovadores e remetiam ao que os historiadores hoje denominam de usos políticos do passado.

O primeiro deles determinava a instalação de uma Comissão Constitucional que teria a função precípua de promover as comemorações do centenário da República no Brasil (art. 63 do Ato das Disposições Constitucionais Transitórias - ADCT). O outro dispositivo estabelecia a realização de um plebiscito nacional, a ser realizado em 1993, quando os brasileiros iriam às urnas escolher qual 
a forma de governo (monarquia ou república) e o sistema de governo (presidencialismo ou parlamentarismo). ${ }^{5} \mathrm{O}$ resultado confirmou o desejo de que o Brasil continuasse republicano e governado por um presidente da República. ${ }^{6}$

Neste artigo, nossa análise se dará em torno da criação, instalação e trabalhos desenvolvidos pela Comissão do Centenário da República e de como ela ratificou uma determinada história oficial que, durante muito tempo, prevaleceu na escola, baseada no culto cívico aos heróis nacionais.

Sabemos que, no decorrer de nossa história, a construção da memória nacional não foi exclusivamente tarefa dos órgãos oficiais de preservação do patrimônio histórico. Outras instâncias contribuíram também para esse fim. Uma delas foi o Parlamento Brasileiro, sobretudo nos momentos de formulação de um novo ordenamento constitucional, durante os processos constituintes.

\section{PARLAMENTO BRASILEIRO E HISTÓRIA NACIONAL: OS DisPositivos DE MEMÓRIA NAS CONSTITUIÇÕES}

Na história política do mundo ocidental, o processo de elaboração da Constituição como lei maior do país é momento ímpar, pois nele ocorrem os debates e proposições tendentes à organização do Estado nacional, mediante a representação emanada da sociedade que, pelo voto popular, elege seus constituintes.

Por sua vez, a Constituição, ordenamento jurídico maior do Estado-nação, tenta sinalizar para o futuro, com normas e dispositivos que delineiam o país que se almeja. No entanto, ao propor um novo texto constitucional que lança as bases para o devir, os constituintes, como legítimos representantes do povo e respaldados no princípio da soberania popular, propõem uma leitura do passado, fazendo dele um uso político, de acordo com os interesses de determinados segmentos da sociedade. Na leitura e apropriação do passado histórico, elegem determinados fatos e personagens que passam a ter a sua memória preservada em monumentos, nos logradouros públicos de nossas cidades, ou instituem um calendário oficial, com datas e efemérides a serem lembradas e comemoradas. Aos artigos, incisos e parágrafos inseridos no texto constitucional relacionados a uma releitura do passado histórico do país denominamos de dispositivos de memória. 
Assim, em quase todas as Constituições brasileiras, iremos encontrar dispositivos de memória que se traduzem no mandamento constitucional de se homenagear ou referenciar determinados fatos e sujeitos históricos, seja pela construção de monumentos, seja pela instituição de datas cívicas e comemorações.

Das sete Constituições de nossa história política, apenas duas delas não trouxeram em seu texto dispositivos de memória. Exatamente aquelas que não passaram pelo crivo de um processo constituinte, tendo sido outorgadas pelos chefes de Estado. Estamos nos referindo às cartas outorgadas de 1824, imposta pelo imperador Pedro I, e de 1937, do ditador Getúlio Vargas, que inaugura o chamado "Estado Novo" (1937-1945).

Nossa primeira Constituição da República (1891) inseriu, de forma pioneira, um dispositivo de memória cujo objetivo era prestar uma solene homenagem a um dos próceres da ideologia positivista que tanto influenciou o movimento republicano: "O Governo Federal adquirirá para a nação a casa em que faleceu o Dr. Benjamin Constant Botelho de Magalhães e nela mandará colocar uma lápide em homenagem à memória do grande patriota - o Fundador da República" (art. $8^{\circ}$ das Disposições Transitórias da Constituição de 1891).

Já os deputados da Assembleia Constituinte de 1933 conseguem inserir no texto constitucional esta deliberação: "Fica o Governo autorizado a abrir o crédito de 300:000\$000, para a ereção de um monumento ao Marechal Deodoro da Fonseca, Proclamador da República" (art. 15 das Disposições Transitórias da Constituição Federal de 1934).

Por sua vez, os Constituintes de 1946, com sua grande maioria formada por juristas e advogados e no contexto da redemocratização que o país vivia após o regime do Estado Novo, prestaram homenagem a Rui Barbosa: “O Governo mandará erigir na Capital da República um monumento a Rui Barbosa, em consagração dos seus serviços à Pátria, à liberdade e à justiça" (Art. 33 do Ato das Disposições Constitucionais Transitórias da Constituição de 1946).

No contexto do regime militar, o Congresso Nacional votou uma proposta de Constituição oriunda do Poder Executivo. A Constituição de 1967 trazia, em seu bojo, um novo dispositivo de memória referente à construção de um monumento a Luiz Alves de Lima e Silva, o Duque de Caxias: "O Governo da 
União erigirá um monumento a Luiz Alves de Lima e Silva, na localidade do seu nascimento, no estado do Rio de Janeiro" (art. 187 do Ato das Disposições Gerais e Transitórias da Constituição de 1967).

Vale ressaltar, também, que apenas o dispositivo de memória da Constituição de 1934, que determinou a construção do Monumento ao Marechal Deodoro, foi efetivamente cumprido. As demais propostas das outras Constituições, por razões diversas, não tiveram a mesma sorte. Alguns monumentos previstos tiveram até projetos escolhidos e premiados em concursos públicos, mas não foram construídos.

A princípio pode-se até questionar o que esses dispositivos de memória têm a ver com a discussão sobre História Pública e sua relação com o ensino de História. Além de se constituírem em representações do passado nacional, os dispositivos de memória, materializados em monumentos históricos, comemorações e datas cívicas, estão intimamente relacionados a uma importante dimensão da História Pública, qual seja, ao binômio História e Público, bem como ao uso que os diferentes sujeitos históricos fazem de seu passado e de sua memória (Oriá, 2018).

No presente ensaio, nossa análise se fará em torno do dispositivo de memória presente na atual Constituição Federal de 1988 que, expressamente, trouxe a determinação de que se criasse uma Comissão Constitucional para comemorar uma grande efeméride de nossa História - o centenário da fundação da República no país (art. 63 do ADCT).

Antes, porém, faz-se necessária uma discussão teórica acerca das comemorações históricas como lugares de memória e de como elas estão atreladas a festas e rituais cívicos, que repercutem em diversos espaços da sociedade, sobretudo no ensino de história nas escolas do país. Bem sabemos que, durante muito tempo, o ensino de história na escola esteve pautado em um currículo por efemérides, no qual emergia, quase sempre, a presença de datas e nomes de heróis nacionais a serem memorizados e exigidos por ocasião dos exames e arguições.

\section{COMEMORAÇÕES E RITUAIS CÍVICOS COMO LUGARES DE MEMÓRIA}

Não há país que, no processo de construção de sua identidade nacional, não promova e cultue seus fatos mais relevantes a serem lembrados na 
posteridade, seja na escrita de sua história, seja na celebração de datas comemorativas e rituais cívicos, com a edição de selos, medalhas e calendários e até mesmo na promulgação de leis e decretos que objetivam a construção da memória nacional, com a edificação de monumentos em praças públicas.

Lembrar, esquecer e comemorar são ações de memória inerentes a nossa existência. Aliás, comemorar é típico das sociedades humanas. Quando se comemora um determinado fato ou acontecimento, o que se está colocando em jogo não é apenas o passado de uma sociedade, mas sim, como essa mesma sociedade quer se constituir no presente e projetar seu futuro. Comemorar não significa apenas celebrar, mas, sobretudo, refletir sobre o passado, que é sempre fonte de infinitas lições para as atuais e futuras gerações.

Em vários momentos da história da civilização ocidental, sobretudo a partir do final do século XIX e início do século XX, tivemos importantes comemorações alusivas a fatos históricos significativos:

O fim do século XIX foi marcado por inúmeras comemorações. Os Centenários das revoluções Americana e Francesa, os IV Centenários das viagens de Colombo e de Vasco da Gama, deram oportunidade aos povos do Ocidente de celebrar esses feitos do passado segundo as questões daquele presente. As exposições internacionais que acompanharam essas comemorações permitiram que cada povo, ao olhar para trás, afirmasse sua modernidade e seu papel em uma escalada evolutiva do ser humano, da barbárie à civilização.

As comemorações de datas nacionais seguem, grosso modo, uma mesma trajetória: organização de comissões executivas nacionais, campanhas de esclarecimento patriótico, organização de eventos cívicos, cortejos fluviais e marítimos, montagem de exposições, inauguração de monumentos, confecção de selos, medalhas, bandeiras e hinos. São esses atos mais frequentes que marcam as comemorações. (Oliveira, 2000, p.185-186)

Por sua vez, comemorações, monumentos históricos, panteões e rituais cívicos constituem, por excelência, o que Pierre Nora convencionou denominar de "lugares de memória". Com o advento da modernidade, caracterizado pela aceleração da história, cada vez mais, o cotidiano afasta-se das vivências da tradição e dos costumes. A memória deixa de ser encontrada no próprio tecido social e passa a necessitar de lugares especiais para ser guardada e preservada em seus laços de continuidade. São os "lugares de memória" 
encarregados dessa função de manutenção dos laços sociais, frente à ameaça do esquecimento. Para esse historiador, "Os lugares de memória nascem e vivem do sentimento que não há memória espontânea, que é preciso criar arquivos, que é preciso manter aniversários, organizar celebrações, pronunciar elogios fúnebres, notariar atas, porque essas operações não são naturais [...] Os lugares de memória são, antes de tudo, restos" (Nora, 1993, p. 13).

Assim, nas comemorações, sobretudo as de cunho histórico, o que se busca é, por meio da memória, refletir sobre nossa experiência histórica como nação e como Estado. Além de constituírem lugares de memória, consideramos que as comemorações, com seus rituais cívicos, são formas genuínas de expressão da nacionalidade, ao revelar os modos de pensar, sentir e valorar o passado histórico. São também formas de expressão da História Pública, pois objetivam levar a amplas audiências uma dada representação do passado.

\section{A Constituição de 1988 e o Centenário da República}

Quando promulgada no dia 5 de outubro de 1988, faltava pouco mais de um ano para que o Brasil completasse cem anos como nação republicana. Os constituintes introduziram, então, importante dispositivo de memória relacionado à comemoração dessa efeméride histórica - o centenário da implantação da República no Brasil:

É criada uma Comissão composta de nove membros, sendo três do Poder Legislativo, três do Poder Judiciário e três do Poder Executivo, ${ }^{7}$ para promover as comemorações do centenário da proclamação da República e da promulgação da primeira Constituição republicana do País, podendo, a seu critério, desdobrar-se em tantas subcomissões quantas forem necessárias. (art. 63 do Ato das Disposições Constitucionais Transitórias)

Esse mesmo dispositivo de memória determinava que, para o desenvolvimento de suas atribuições, a Comissão promoveria estudos, debates e avaliações sobre nossa evolução política, social, econômica e cultural. Para tanto, poderia também articular-se com os governos estaduais e municipais e até mesmo com instituições públicas e privadas que desejassem aderir ao projeto comemoracionista. Ficava claro, portanto, que o principal objetivo da Comissão seria o de 
repensar o Brasil: "As comemorações que se iniciaram em 15 de novembro de 1988, e estendem-se até 1991, são também um momento de repensar o Brasil. Os fatos que as motivam são importantes por si mesmos, e como tais devem ser lembrados. Mas, ao lado de seu significado histórico, ensejam a reflexão sobre a consolidação da república e da democracia, a que hoje assistimos, e sobre o futuro da liberdade em nossa terra" (Brasil, 1995, p. 13).

Um dos membros da referida Comissão, senador Marco Maciel (PFL-PE), fazia questão de registrar esse aspecto por ocasião do estabelecimento de ações e propostas a serem realizadas pelo Poder Público, com a participação das unidades da federação, a mobilização da sociedade e até mesmo em parceria com a iniciativa privada:

Mais importante que festejar - convém frisar - é fazer uma reflexão crítica sobre os cem últimos anos - sob o aspecto político, social, econômico, cultural e institucional. Enfim, ao rejeitarmos em 1889 a Monarquia, buscou-se novos tempos para o Brasil. Precisamos, portanto, fazer um balanço do país nos seus mais diferentes aspectos. Não foi isso que vimos por ocasião dos 200 anos da Constituição norte-americana e o bicentenário da Revolução Francesa?

Ademais, em 7 de setembro de 1993, também por força do dispositivo aprovado na Constituição, será efetuado plebiscito para definir se continuaremos República ou retornaremos ao regime monárquico e qual deverá ser o sistema de governo (parlamentarismo ou presidencialismo). (Maciel, 1995, p. 40)

Antes mesmo da promulgação da Carta de 1988, o governo federal já havia editado o Decreto no 96.630, de 31 de agosto de 1988, que "cria o Programa Nacional do Centenário da República e Bicentenário da Inconfidência Mineira", cujo objetivo era estabelecer uma programação para as comemorações do Bicentenário da Inconfidência Mineira e do Centenário da Implantação da República no Brasil, que deveria ocorrer no ano de 1989.

O referido Decreto é encampado pela Comissão Constitucional, razão pela qual não houve edição de nenhum outro ato normativo para regulamentar o dispositivo constitucional assente no art. 63 do ADCT. Apenas foi elaborado um Regimento para disciplinar as atividades da Comissão Constitucional. Nele, ampliava-se o escopo das comemorações que, pelo art. $1^{\circ}$, parágrafo primeiro, passava a ser, além do Centenário da República, as comemorações alusivas ao Centenário da Primeira Constituição Republicana (1891), o Centenário 
da Bandeira Nacional (1889), o Bicentenário da Inconfidência Mineira (1789) e outras datas de evocação republicana.

O ano de 1989 é bastante emblemático das transformações geopolíticas e sociais pelas quais passou o mundo ocidental, marcado por uma nova leitura historiográfica do movimento revolucionário francês, por conta das comemorações de seu bicentenário (1789-1989) e devido à Queda do Muro de Berlim, que marcou o início da derrocada do modelo socialista de governo nos países do Leste europeu.

No Brasil, em particular, as comemorações do centenário da República coincidiam com a realização de eleições diretas para a Presidência da República, após uma abstinência eleitoral de mais de 20 anos, imposto pelo regime militar de 1964.

Numa análise sucinta da atuação da Comissão Constitucional, podemos destacar duas importantes ações que foram propostas e executadas em torno da preservação da memória nacional e de divulgação da história do Brasil.

A primeira dessas ações refere-se à restauração de importantes sítios históricos relacionados ao imaginário republicano, todos eles na cidade do Rio de Janeiro, por ter sido palco dos acontecimentos históricos que resultaram na implantação da República. Foram, assim, restaurados e devolvidos ao público o Museu da República, mais conhecido como Palácio do Catete; a Casa de Deodoro; a Casa de Benjamin Constant, o antigo Palácio Itamaraty e, em Niterói, a Praça da República, que recebeu de volta o monumento "Triunfo à República”.

A Comissão Nacional sugeriu ao governo do estado do Rio de Janeiro que procedesse ao tombamento de importantes monumentos históricos que evocam personagens de destaque na República. Assim, o Instituto Estadual do Patrimônio Cultural (Inepac-RJ) instaurou processo de tombamento dos seguintes bens culturais: os monumentos ao Marechal Floriano Peixoto, ao Marechal Deodoro da Fonseca e a Quintino Bocaiúva, todos no Rio de Janeiro, e a Praça da República, em Niterói.

Outra importante iniciativa da Comissão foi a criação de um projeto editorial, intitulado "Biblioteca da República", que pretendia editar cerca de 200 livros, alguns já esgotados, e que teria seis coleções básicas, a saber: Documentos Republicanos; Brasil; Inéditos; Casas da República; América, e Cidadão. A primeira a ser lançada foi a "Coleção do Cidadão", com edições populares e 
tiragens de baixo custo, constante dos seguintes títulos: Constituição Federal de 1988; História Política do Brasil, de Pedro Calmon; Antologia da Poesia Brasileira, de Manuel Bandeira, e Antologia de Contos, de Machado e Assis. A Biblioteca da República publicou, em regime de coedição, várias teses e dissertações da área de História e Ciências Sociais defendidas nos diferentes programas de pós-graduação do país.

Como forma de mobilizar a sociedade realizou-se um concurso nacional para a escolha da logomarca da efeméride. Dele participaram artistas, estudantes e profissionais de artes gráficas e design. No total, foram inscritas 496 propostas de diferentes pontos do território nacional. A escolha recaiu sobre o trabalho dos designers Victor Burton e Isabela Perrota que, evocando um trecho do Hino da República, fizeram um desenho das asas brancas de um pássaro, representando a liberdade, com os dizeres: "REPÚBLICA 100 ANOS - A LIBERDADE ABRE AS ASAS SOBRE NÓS!” (Figura 1).

Figura 1 - Logomarca do Centenário da República (1889-1989)

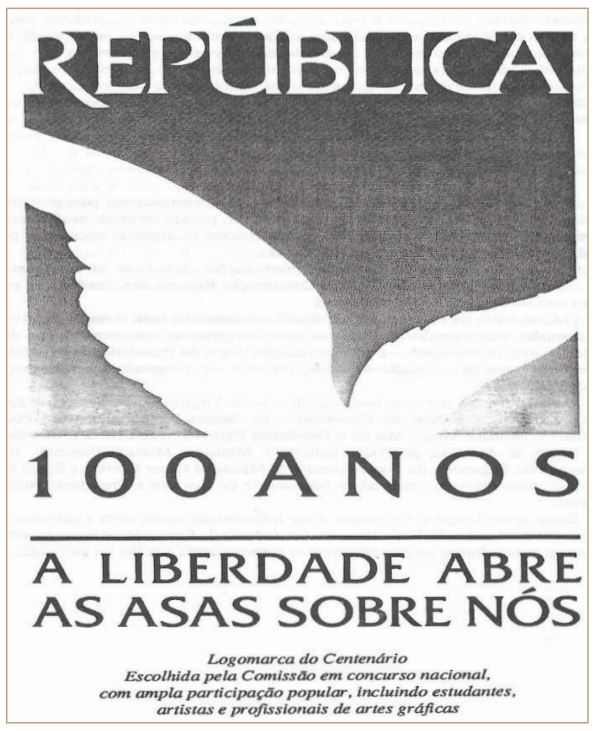

Fonte: Domínio Público.

Com a logomarca escolhida, foi publicada na imprensa escrita e bastante divulgada nos meios de comunicação a propaganda oficial da Comemoração 
do Centenário da República, com o título "A Liberdade abre as asas sobre nós..." (Figura 2).

O texto que acompanha a propaganda é bastante elucidativo da visão de República que se construiu no imaginário brasileiro. Nele, percebe-se uma nítida visão teleológica de nosso passado histórico, ou seja, o Brasil estava, desde os tempos coloniais, fadado ao destino republicano. Os movimentos sociais ocorridos no período já evidenciavam isso, sobretudo a Inconfidência Mineira. Nesse sentido, a imagem de Tiradentes aparece em destaque junto a um trecho fac-similar de sua sentença condenatória. Ao centro destaca-se, em primeiro plano, Deodoro da Fonseca, seguido das imagens de Rui Barbosa e Benjamin Constant. Ao lado desses personagens históricos há uma reprodução do jornal Correio do Povo noticiando a Proclamação da República.

Como a Comissão deveria também celebrar nossa primeira Constituição Republicana de 1891, há uma imagem da capa desse documento histórico, do lado direito da propaganda. $\mathrm{O}$ texto termina com uma saudação laudatória: "Viva a República. Viva o Povo Brasileiro", seguido da logomarca da efeméride. O texto oficial é assinado pela Comissão Constitucional do Centenário da República, Governo Federal, Congresso Nacional e Poder Judiciário.

Figura 2 - Propaganda alusiva ao Centenário da República (1889-1989)

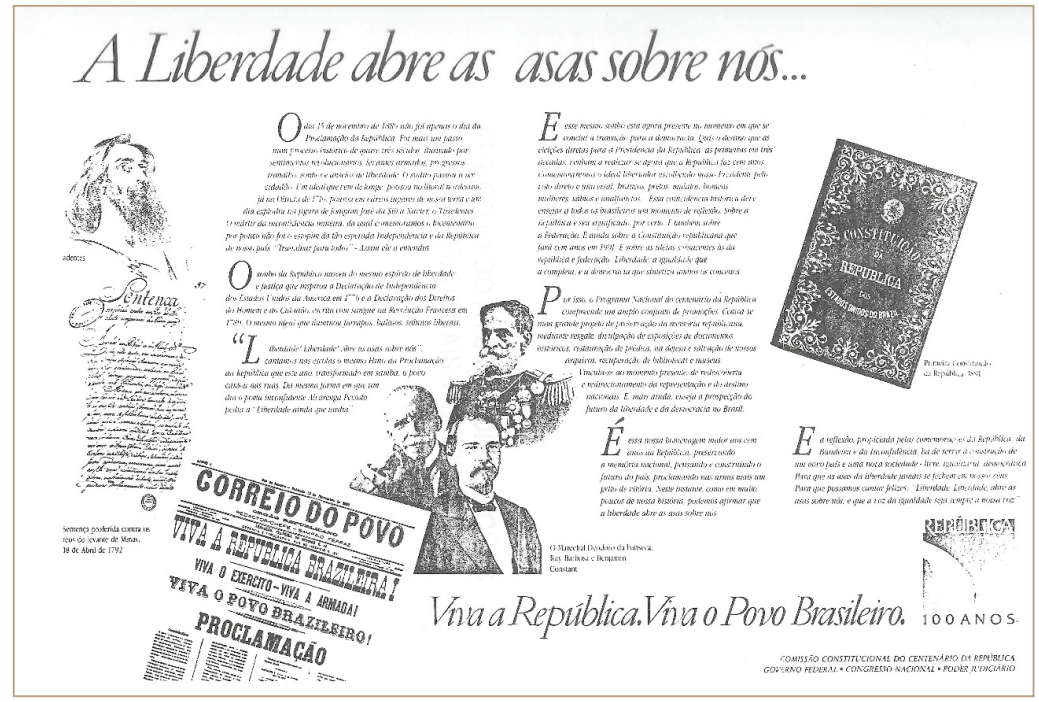

Fonte: Domínio Público. 
Além da logomarca, emitiu-se, também, um selo comemorativo ao Centenário da República pela Empresa Brasileira de Correios e Telégrafos (ECT), que usou do quadro Alegoria da República, de autor anônimo, pertencente ao acervo da Fundação Oscar Americano. Nele se veem duas imagens: em destaque, os republicanos liderados por Deodoro que empunham a nova bandeira nacional e a entregam a uma mulher - supostamente representando a República -, e, ao fundo, o banimento da família real.

Figura 3 - Selo Comemorativo ao Centenário da República

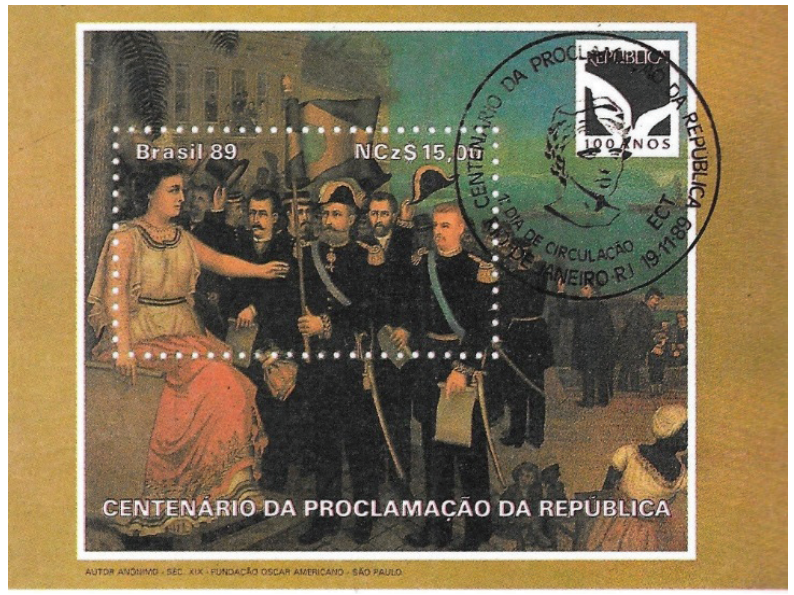

Fonte: Domínio Público.

Figura 4 - Moeda Comemorativa ao Centenário da República

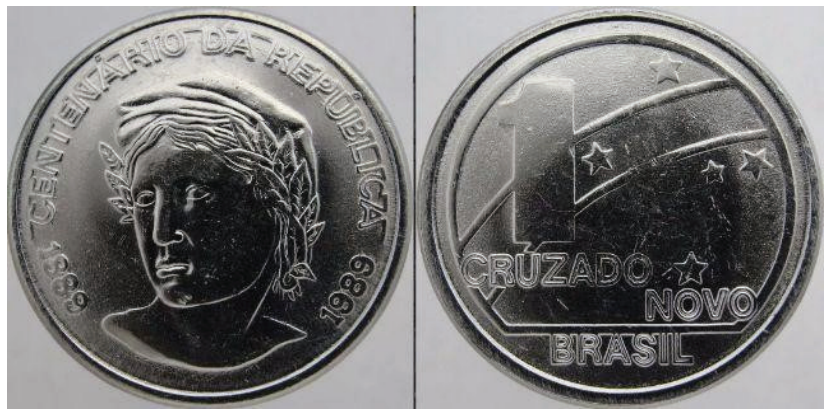

Fonte: Domínio Público. 
Ressalte-se que houve críticas na imprensa pelo fato de que as comemorações de tão importante efeméride foram realizadas de forma improvisada e sem o brilho necessário para um evento dessa natureza. O ministro da Cultura, José Aparecido de Oliveira, pronunciou-se a respeito, justificando-se em nome da Comissão Constitucional:

A imprensa em geral escreveu que a Comissão Constitucional para promover as celebrações do Centenário da República teve um pecado original: nasceu tarde. Daí resultaram ações improvisadas, exame insuficiente de algumas iniciativas, precariedade do desempenho de tarefas importantes. Mas é certo que o prazo para as comemorações estende-se até fevereiro de 1991, data da promulgação da primeira Constituição Republicana.

O Centenário da Proclamação da República coincidiu com o maior ato cívico para assinalar a data histórica quando as atenções gerais se concentravam em dois acontecimentos momentosos - a primeira eleição direta do Presidente da República, depois de 30 anos de usurpação do direito do povo - e o segundo turno da eleição presidencial. (Brasil, 1995, p. 47)

Na prática, as comemorações se estenderam até o ano de 1992, quando se celebrou o bicentenário da morte de Tiradentes (21 abr. 1792). Com a atuação do embaixador José Aparecido de Oliveira junto ao governo de Portugal, as comemorações culminaram na concessão de anistia, oficial e solenemente, pelo governo português, a Joaquim José da Silva Xavier, o Tiradentes. Estava, pois, resgatada uma dívida histórica: Tiradentes não era mais traidor, mas herói nacional em toda sua plenitude.

\section{Concluindo: os Heróis NA Escola E No PANTEÃo}

No rol das atividades desenvolvidas pela referida Comissão constava a sugestão para que os primeiros a terem seus nomes inscritos no Panteão da Pátria fossem os de Tiradentes (líder e mártir da Inconfidência Mineira), Deodoro (proclamador da República) e Prudente de Morais (presidente da Constituinte Republicana de 1891).

Por que esses personagens e não outros foram selecionados? O que levou a Comissão a referendar somente os nomes de Tiradentes e Deodoro? 
Sabemos que a memória de Joaquim José da Silva Xavier, mais conhecido como Tiradentes, passou a ser promovida com maior intensidade desde a instalação da República. A data de sua morte (21 de abril) tornou-se feriado nacional, a partir de 1890, com o Decreto $\mathrm{n}^{\circ} 155-\mathrm{B}$, de 14 de janeiro de 1890, que declara os dias de festa nacional. No decorrer da história, a imagem de Tiradentes foi moldada e apropriada por movimentos ideológicos os mais diferentes. $\mathrm{Na}$ Era Vargas (1930-1945), por exemplo, sua memória foi novamente acionada com a elevação da cidade de Ouro Preto (antiga Vila Rica e palco do movimento) a Monumento Nacional (1933) e a criação do Panteão dos Inconfidentes (1942).

Até mesmo o regime militar que se instalou no país após o golpe de 1964 usou da imagem desse herói nacional para se legitimar no poder. Tiradentes, que em vida era alferes (cargo de natureza militar), foi promovido à condição de "Patrono Cívico da Nação Brasileira", pela Lei no 4.897, de 1965. Além de declarar "Patrono Cívico do Brasil", a lei fazia questão de que o dia 21 de abril de 1966 se revestisse de grandes festividades, a serem comemoradas, em todas as repartições públicas do país, incluindo as escolas, mediante a colocação da efígie do homenageado. Retomava-se, portanto, o espírito cívico em torno da figura de Tiradentes, que era reconhecido como "glorioso republicano". Adotou-se como modelo para a reprodução da efígie de Joaquim José da Silva Xavier a estátua de Tiradentes, erigida na antiga sede da Câmara dos Deputados, no Rio de Janeiro (Palácio Tiradentes).

A imagem de Tiradentes construída pelo regime republicano e que ficou para a posteridade, registrada em quadros, monumentos e bustos e reproduzida nos livros didáticos, é a do herói e mártir. Tiradentes passou a ser o "Cristo Cívico" da nação, pois à semelhança de Jesus, ele sacrificou sua própria vida em prol da emancipação do país (Carvalho, 1990; Milliet, 2001).

Já o nome de Deodoro da Fonseca foi escolhido por ser aquele que, formalmente, implantou a República no Brasil e ter sido nosso primeiro presidente, embora a disputa pela paternidade do novo regime seja reivindicada por outros atores, a exemplo de Benjamin Constant e Floriano Peixoto.

Vale ressaltar que a ideia de construção de um Panteão nacional não era nova. No Brasil, a mudança para o regime republicano exigiu a constituição de um novo imaginário político em busca de uma maior legitimação, uma vez que a implantação da República se deu por meio de um golpe militar que baniu a família imperial do país (Fagundes, 2017). 
Assim, em 1891, no decorrer dos trabalhos da Constituinte, eis que surge, durante o debate parlamentar, a ideia de se construir um Panteão para o culto cívico aos grandes homens da Pátria brasileira. A proposta era de autoria do deputado federal pelo Distrito Federal Aristides Lobo. Como forma de homenagear um dos próceres do movimento republicano, Lobo propôs a criação de um Panteão ao fundador da República Benjamin Constant (1836-1891): "Que seja creado um Pantheon em honra aos grandes homens da Patria Brazileira, onde serão inhumados os que assim bem merecerem da Patria, conforme decretarem os futuros Congressos, sendo desde já indicado o Dr. Benjamin Constant" (Anais da Constituinte, 1890, v. 2, p. 26, grifos do autor).

A medida proposta pelos deputados constituintes de 1891 dá continuidade à criação de uma simbologia para o recém-instalado regime republicano que necessitava de heróis, signos e imagens para sua legitimação perante a sociedade. Nesse sentido, as palavras da historiadora Valéria Salgueiro são elucidativas: "O Congresso Constituinte republicano punha em prática, dessa forma, o princípio positivista de veneração cívica através do culto a homens ilustres em substituição à adoração dos santos católicos, erguendo-lhes um panteão do mesmo modo que tradicionalmente se erguiam templos às divindades míticas religiosas. (Salgueiro, 2008, p. 100).

Durante a ditadura militar, após a morte do ex-presidente Juscelino Kubitschek de Oliveira, tramitou na Câmara dos Deputados o Projeto de Lei no 1.496, de 1979, de autoria do deputado Ítalo Conti, que "dispõe sobre o Panteão a ser erguido na Praça dos Três Poderes, em Brasília, destinado a abrigar os restos mortais do presidente Juscelino Kubitschek de Oliveira, e determina outras providências". Como Juscelino, em vida, fez oposição aos militares, o projeto não logrou êxito à época. O Memorial JK, que contém os restos mortais do ex-presidente, só foi inaugurado no ano de 1981, e em local menos nobre do que a Praça dos Três Poderes - epicentro da vida política nacional.

A ideia de construção de um Panteão da Pátria foi retomada no contexto da redemocratização do país (1985-1988) e teve como inspiração a morte de outro político, no caso, Tancredo de Almeida Neves, eleito primeiro presidente civil após o regime militar e que, por motivo de doença e posterior falecimento, não chegou a tomar posse no cargo. Assim, na data máxima da nacionalidade, no dia 7 de setembro de 1986, foi inaugurado, na Praça dos Três Poderes, com projeto de Oscar Niemeyer, o Panteão da Pátria, cujo nome completo é 
“Panteão da Liberdade e da Democracia Tancredo Neves" (Figura 5), em homenagem ao político mineiro.

Figura 5 - Panteão da Liberdade e da Democracia Tancredo Neves (1986)

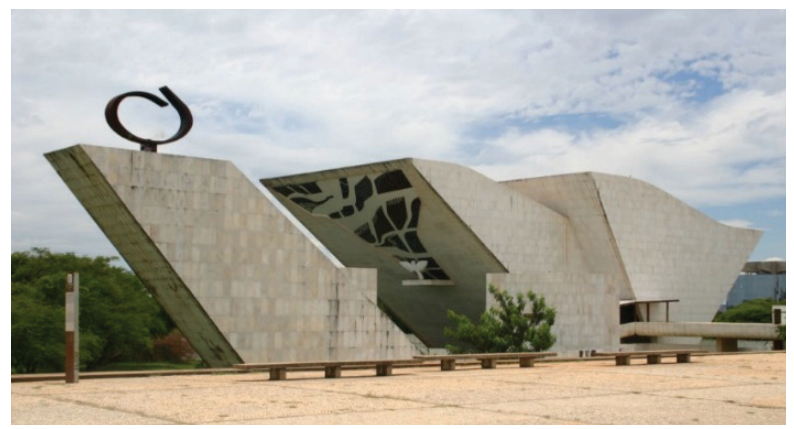

Fonte: Acervo Arquivo Público do Distrito Federal.

Diferentemente de outros panteões, o Panteão da Pátria não contém os restos mortais dos heróis nacionais. Lá consta um livro de aço, denominado "Livro dos Heróis da Pátria" (Figura 6), com o nome dos brasileiros já falecidos que, em vida, se destacaram pela defesa do ideário da liberdade e da democracia. Os nomes dos homenageados estão inscritos nesse livro de aço, no qual lhes é concedido o atributo de "Heróis da Pátria". Constam, em cada página de metal, seus nomes e biografias.

Figura 6 - Livro de Aço dos Heróis da Pátria. Panteão da Liberdade e da Democracia Tancredo Neves

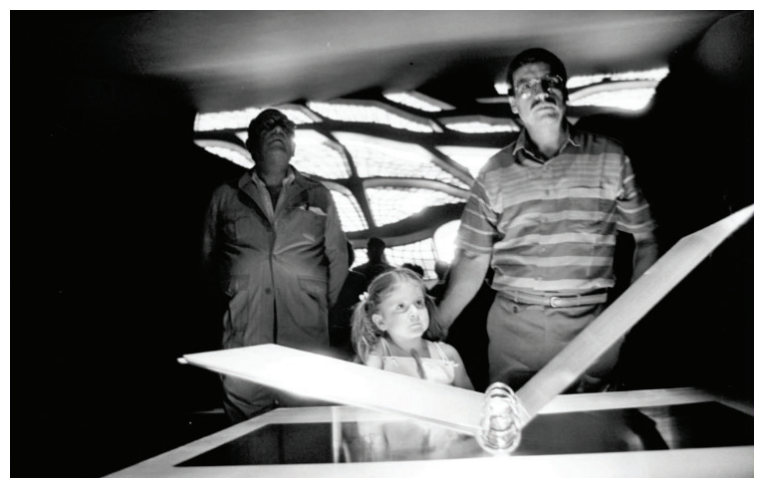

Fonte: Acervo do Arquivo Público do Distrito Federal. 
José Aparecido de Oliveira, então ministro da Cultura à época, encaminhou ao então presidente da República, José Sarney, uma exposição de motivos que fundamentou a proposta de inscrição de nomes brasileiros falecidos que deveriam constar no Panteão da Pátria. Trata-se do Projeto de Lei no 4.087, de 1989, que "dispõe sobre a homenagem à memória de brasileiros considerados 'Heróis da Pátria”". O referido projeto tramitou na Câmara dos Deputados, tendo sido apreciado na primeira das comissões permanentes - Comissão de Constituição e Justiça e de Redação (CCJR), que o rejeitou por considerar injurídico, visto que essa homenagem poderia ser tratada em nível de decreto pelo Poder Executivo. Nesse sentido, a proposição foi arquivada, sem que se analisasse seu mérito pela Comissão de Educação e Cultura da Câmara dos Deputados.

Em vista da proximidade das comemorações do Centenário da República, cujo ápice seria o dia 15 de novembro de 1989, o Executivo encaminhou ao Congresso Nacional uma Medida Provisória sobre a matéria que depois foi convertida na Lei n n $^{7.919}$, de 11 de dezembro de 1989, que "dispõe sobre a inscrição do nome de Tiradentes e Deodoro da Fonseca no Livro dos Heróis da Pátria". O art. 1 da referida Lei fazia alusão expressa à comemoração das duas efemérides históricas daquele ano de 1989: “Em comemoração do bicentenário da Inconfidência Mineira e do centenário da Proclamação da República, são inscritos no Livro dos Heróis da Pátria os nomes de Joaquim José da Silva Xavier, o Tiradentes, e do Marechal Manoel Deodoro da Fonseca”.

Assim, em pleno feriado nacional, dia 15 de novembro de 1989, quando os cidadãos brasileiros foram, em primeiro turno, votar para a escolha do futuro presidente do Brasil, a solenidade no Panteão da Pátria fazia uma evocação e uso político do passado ao inserir os nomes de Tiradentes e Deodoro no rol dos heróis nacionais.

Estava, assim, oficialmente inaugurado nosso Panteão da Pátria. Criava-se um novo lugar de memória nacional, ao tempo em que se fortaleciam os mesmos heróis identificados com o ideário republicano - Tiradentes, nosso herói por excelência, e Deodoro da Fonseca, um dos fundadores da República e primeiro presidente do país. E mais: esses personagens e os fatos que protagonizaram já presentes na historiografia didática, são, agora, consagrados no "Altar da Pátria". 
Este ano de 2019 assinala os 130 anos da implantação do regime republicano no Brasil. Daqui a 3 anos, teremos outra importante efeméride - o Bicentenário da Independência do Brasil (1822-2022). Com certeza, o Poder Público, ${ }^{8}$ em suas várias instâncias, aliado a segmentos da sociedade civil e da iniciativa privada, irá evocar nosso passado histórico, transformando-o em uma grande comemoração, quando serão criados novos lugares de memória e formuladas novas interpretações e projeções para o país. Afinal, como tão bem afirmou o diplomata e historiador pernambucano Evaldo Cabral de Mello, "toda vez que se organiza uma comemoração do passado, o que se está comemorando é uma visão de presente" (Oliveira, 2000, p. 186).

\section{REFERENCIAS}

BRASIL. Anais da Constituinte. Rio de Janeiro, 1890, v. 1/2. Disponível em: http:// bd.camara.gov.br/bd/handle/bdcamara/13616 Acesso em 25 fev. 2019.

BRASIL. Comissão Constitucional do Centenário da República e da Primeira Constituição Republicana. Relatório. Trabalho organizado por Elaine Marinho Farias e Leonardo Leite Neto. Brasília: Senado Federal, 1995.

BRASIL. Constituição (1891). Constituição da República dos Estados Unidos do Brasil. Rio de Janeiro, 1891. Disponível em: http://www.planalto.gov.br/ccivil_03/ Constituicao/Constitui\%C3\%A7ao91.htm Acesso em: 25 fev. 2019.

BRASIL. Constituição (1934). Constituição da República dos Estados Unidos do Brasil. Rio de Janeiro, 1934. Disponível em: http://www.planalto.gov.br/ccivil_03/ Constituicao/Constitui\%C3\%A7ao34.htm Acesso em: 25 fev. 2019.

BRASIL. Constituição (1946). Constituição dos Estados Unidos do Brasil. Rio de Janeiro, 1946. Disponível em: http://www.planalto.gov.br/ccivil_03/Constituicao/ Constitui\%C3\%A7ao46.htm. Acesso em: 25 fev. 2019.

BRASIL. Constituição (1967). Constituição da República Federativa do Brasil. Disponível em: http://www.planalto.gov.br/ccivil_03/Constituicao/Constituicao67. htm. Acesso em: 25 fev. 2019.

BRASIL. Constituição (1988). Constituição da República Federativa do Brasil. Brasília: Senado Federal: Centro Gráfico, 1988.

BRASIL. Decreto $n^{\circ} 155-B$, de 14 de janeiro de 1890. Declara os dias de festa nacional. Disponível em: http://www2.camara.leg.br/legin/fed/decret/1824-1899/decreto-155-b-14-janeiro-1890-517534-publicacaooriginal-1-pe.html. Acesso em: 25 fev. 2019. 
BRASIL. Decreto $n^{\circ} 171$, de 20 de janeiro de 1890. Conserva o Hymno Nacional e adopta o da Proclamação da República. Disponível em: http://www.planalto.gov. br/ccivil_03/decreto/1851-1899/D171.htm. Acesso em: 25 fev. 2019.

BRASIL. Decreto $n^{\circ}$ 96.630, de 31 de agosto de 1988, que cria o Programa Nacional do Centenário da República e Bicentenário da Inconfidência Mineira. Disponível em: http://www2.camara.leg.br/legin/fed/decret/1988/decreto-96630-31-agosto-1988-447368-publicacaooriginal-1-pe.html. Acesso em: 25 fev. 2019.

BRASIL. Decreto de 6 de setembro de 2016, que institui a Comissão Interministerial Brasil 200 Anos. Disponível em: http://www.planalto.gov.br/ccivil_03/_ato20152018/2016/dsn/Dsn14408.htm. Acesso em: 25 fev. 2019.

BRASIL. Emenda Constitucional $n^{\circ} 1$, de 17 de outubro de 1969, que edita o novo texto da Constituição Federal de 1967. Disponível em: http://www.planalto.gov.br/ccivil_03/Constituicao/Emendas/Emc_anterior1988/emc01-69.htm. Acesso em: 25 fev. 2019.

BRASIL. Lei $n^{\circ}$ 4.897, de 12 de dezembro de 1965, que declara Joaquim José da Silva Xavier, o "Tiradentes", patrono cívico da nação brasileira. Disponível em: http:// www2.camara.leg.br/legin/fed/lei/1960-1969/lei-4897-9-dezembro-1965-368995-publicacaooriginal-1-pl.html. Acesso em: 25 fev. 2019.

BRASIL. Lei $n^{\circ} 5.700$, de $1^{\circ}$ de setembro de 1971, que dispõe sobre a forma e a apresentação dos Símbolos Nacionais, e dá outras providências. Disponível em: https:// www2.camara.leg.br/busca/?tiponormaT $=$ Lei+Ordinária\&o=relevance\&v=legisla cao\&colecao $=\mathrm{T} \&$ numero $=5700 \& a n o=1971 \& \mathrm{x}=14 \& \mathrm{y}=16$. Acesso em: $25 \mathrm{fev} .2019$.

BRASIL. Lei $n^{\circ}$ 7.919, de 11 de dezembro de 1989, que "dispõe sobre a inscrição do nome de Tiradentes e Deodoro da Fonseca no Livro dos Heróis da Pátria". Disponível em: https://www.planalto.gov.br/ccivil_03/LEIS/1989_1994/L7919. htm. Acesso em: 25 fev. 2019.

BRASIL. Lei $n^{\circ} 11.597$, de 29 de novembro de 2007. Dispõe sobre a inscrição de nomes no Livro dos Heróis da Pátria. Disponível em: http://www.planalto.gov.br/ccivil_03/_Ato2007-2010/2007/Lei/L11597.htm. Acesso em: 25 fev. 2019.

BRASIL. Projeto de Lei $n^{\circ} 1.496$, de 28 de junho de 1979, que dispõe sobre o Panteão a ser erguido na Praça dos Três Poderes, em Brasília, destinado a abrigar os restos mortais do presidente Juscelino Kubitschek de Oliveira, e determina outras providências. Disponível em: http://www.camara.gov.br/proposicoesWeb/fichadetramit acao?idProposicao=192854. Acesso em: 25 fev. 2019.

BRASIL. Projeto de Lei $n^{\circ} 4.087$, de 9 de novembro de 1989, que dispõe sobre a homenagem à memória de brasileiros considerados "Heróis da Pátria". Disponível em: http://www.camara.gov.br/proposicoesWeb/fichadetramitacao?idProposic ao $=218665$. Acesso em: 25 fev. 2019. 
CARVALHO, José Murilo de. A formação das almas: o imaginário da República no Brasil. São Paulo: Companhia das Letras, 1990.

FAGUNDES, Luciana P. Do exílio ao Panteão: D. Pedro II e seu reinado sob olhares republicanos. Curitiba: Prismas, 2017.

MACIEL, Marco. Centenário da República - ações e propostas. In: BRASIL. Comissão Constitucional do Centenário da República e da Primeira Constituição Republicana. Relatório. Trabalho organizado por Elaine Marinho Farias e Leonardo Leite Neto. Brasília: Senado Federal, 1995.

MILLIET, Maria Alice. Tiradentes: o corpo do herói. São Paulo: Martins Fontes, 2001.

NORA, Pierre. Entre Memória e História: a problemática dos lugares. História e Cultura. Projeto História (Revista do Programa de Estudos Pós-Graduados em História do Departamento de História da PUC-SP), São Paulo, n. 10, 1993.

OLIVEIRA, Lúcia L. Imaginário Histórico e Poder Cultural: as Comemorações do Descobrimento. Estudos Históricos, Rio de Janeiro, v. 14, n. 26, p. 183-202, 2000.

ORIÁ, Ricardo. História Pública e Monumentos: a narrativa visual do passado nacional. In: ALMEIDA, Juniele R.; MENESES, Sônia. História Pública em debate: patrimônio, educação e mediação do passado. São Paulo: Letra e Voz, 2018.

SALGUEIRO, Valéria. De Pedra e Bronze: um estudo sobre monumentos. O Monumento a Benjamin Constant. Niterói: Ed. UFF, 2008.

\section{NOTAS}

${ }^{1}$ Pós-Doutor em História pela Universidade Federal Fluminense (UFF).

${ }^{2}$ Letra de Medeiros e Albuquerque, música de Leopoldo Miguez (1890).

${ }^{3}$ Resultado de um concurso público, esse hino foi composto para ser o hino nacional oficial do país. A peça terminou não sendo usada por decisão do próprio marechal Deodoro, que editou o Decreto no 171, de 20 de janeiro de 1890, estabelecendo que esse seria o Hino da Proclamação da República e conservando-se como Hino Nacional a composição musical de Francisco Manoel da Silva. Somente em 6 de setembro de 1922, às vésperas das comemorações do centenário da Independência, oficializou-se a letra definitiva do Hino Nacional, de autoria de Osório Duque Estrada.

4 A Lei no 5.700, de 1971, que "dispõe sobre a forma e a apresentação dos Símbolos Nacionais, e dá outras providências", estabelece, em seu art. 39, que: "É obrigatório o ensino do desenho e do significado da Bandeira Nacional, bem como do canto e da interpretação da letra do Hino Nacional em todos os estabelecimentos de ensino, públicos ou particulares, do primeiro e segundo graus. Parágrafo único: Nos estabelecimentos públicos e privados de ensino fundamental, é obrigatória a execução do Hino Nacional uma vez por semana". 
5 “Art. 2. No dia 7 de setembro de 1993 o eleitorado definirá, através de plebiscito, a forma (república ou monarquia constitucional) e o sistema de governo (parlamentarismo ou presidencialismo) que devem vigorar no País (Ato das Disposições Constitucionais Transitórias da Constituição Federal de 1988)". Posteriormente, Emenda Constitucional alterou a data de realização do plebiscito que foi realizado no dia 21 de abril de 1993, feriado nacional alusivo à morte do herói nacional Tiradentes.

${ }^{6}$ A atual Constituição previa a realização de plebiscito e, em 21 de abril de 1993, realizou-se, para definição da forma e sistema de governo da República, quando, de um universo de 90.256.629 eleitores, compareceram 67.010.241, e o resultado foi a aprovação da República como forma de governo, com 44.266 .433 votos, e do presidencialismo como sistema de governo, com 37.156.841 votos (Fonte: http://www.tse.jus.br/eleitor/glossario/termos/ plebiscito).

${ }^{7}$ A Comissão era constituída pelos seguintes membros: Saulo Ramos, ministro da Justiça; José Aparecido de Oliveira, ministro da Cultura; senador Marco Maciel; deputados Egydio Ferreira Lima e Bonifácio de Andrada; ministro José Fernando Dantas (STJ); ministro Aldo Fagundes (STM); ministro Marcelo Pimentel (TST) e o sr. Virgílio Costa (secretário da Comissão Especial da Memória dos Presidentes e coordenador do Programa Nacional do Centenário da República e Bicentenário da Inconfidência Mineira). A Secretaria Executiva era constituída por representantes de órgãos da Administração Pública Federal, a saber: Jobson Arruda (Conselho Nacional de Desenvolvimento Científico e Tecnológico - CNPq); Osvaldo Peralva (Instituto Nacional do Livro - INL); Manoel Marques Formiga (Instituto Nacional de Estudos e Pesquisas Educacionais - Inep); Celina Moreira Franco (Arquivo Nacional); Nilza Teixeira (Câmara dos Deputados) e Branca Borges (Senado Federal).

${ }^{8} \mathrm{Na}$ gestão do governo de Michel Temer foi instituída pelo Decreto de 6 de setembro de 2016 a Comissão Interministerial Brasil 200 Anos, "com a finalidade de coordenar as atividades, os eventos e os projetos relacionados às comemorações do ducentésimo aniversário da Independência da República Federativa do Brasil", devendo sua coordenação ser feita pelo Ministério da Cultura (hoje, Secretaria Especial da Cultura do Ministério da Cidadania).

Artigo recebido em 15 de abril de 2019. Aprovado em $1^{\circ}$ de julho de 2019. 